\title{
Long-term monitoring of nitrate transport to drainage from three agricultural clayey till fields
}

\author{
V. Ernstsen ${ }^{1}$, P. Olsen ${ }^{2}$, and A. E. Rosenbom ${ }^{1}$ \\ ${ }^{1}$ Geological Survey of Denmark and Greenland, Øster Voldgade 10, 1350 Copenhagen, Denmark \\ ${ }^{2}$ Aarhus University, Department of Agroecology, Blichers Allé 20, 8830 Tjele, Denmark \\ Correspondence to: V. Ernstsen (ve@geus.dk)
}

Received: 9 December 2014 - Published in Hydrol. Earth Syst. Sci. Discuss.: 15 January 2015

Revised: 29 June 2015 - Accepted: 9 July 2015 - Published: 7 August 2015

\begin{abstract}
The application of nitrogen (N) fertilisers to crops grown on tile-drained fields is required to sustain most modern crop production, but it poses a risk to the aquatic environment since tile drains facilitate rapid transport pathways with no significant reduction in nitrate. To maintain the water quality of the aquatic environment and the provision of food from highly efficient agriculture in line with the EU's Water Framework Directive and Nitrates Directive, field-scale knowledge is essential for introducing water management actions on-field or off-field and producing an optimal differentiated N-regulation in future. This study strives to provide such knowledge by evaluating on 11 years of nitrate- $\mathrm{N}$ concentration measurements in drainage from three subsurfacedrained clayey till fields (1.3-2.3 ha) representing approximately $71 \%$ of the surface sediments in Denmark dominated by clay. The fields differ in their inherent hydrogeological field settings (e.g. soil-type, geology, climate, drainage and groundwater table) and the agricultural management of the fields (e.g. crop type, type of $\mathrm{N}$ fertilisers and agricultural practices). The evaluation revealed three types of clayey till fields characterised by: (i) low net precipitation, high concentration of nitrate- $\mathrm{N}$, and short-term low intensity drainage at air temperatures often below $5^{\circ} \mathrm{C}$; (ii) medium net precipitation, medium concentration of nitrate- $\mathrm{N}$, and short-term medium-intensity drainage at air temperatures often above $5^{\circ} \mathrm{C}$; and (iii) high net precipitation, low concentration of nitrate- $\mathrm{N}$ and long-term high intensity drainage at air temperatures above $5^{\circ} \mathrm{C}$. For each type, on-field water management actions, such as the selection of crop types and introduction of catch crops, appeared relevant, whereas offfield actions only seemed relevant for the latter two field types given the temperature-dependent reduction potential
\end{abstract}

of nitrate off-field. This initial well-documented field-scale knowledge from fields that are representative of large areas in Denmark is a first step towards establishing a differentiated $\mathrm{N}$-regulation for clayey till areas. Additionally, it provides a unique starting point by identifying important parameters for future mapping of catchment-scale variations in nitrate concentrations and fluxes.

\section{Introduction}

Future regulations covering aquatic environments under the Nitrates Directive (EEC, 1991), the EU Water Framework Directive (EC, 2000), the EU Groundwater Directive (EC, 2006) and additional national laws and regulations (DanishEPA, 2012) call for long-term monitoring data to describe the complex interaction between soil, geology, geochemistry and hydrology at a local level as well on larger scales. Since Denmark presented its first national hydrological action plan in 1985, several political agreements have adopted the aim of protecting the aquatic environment and nature in general. Recently, the Danish Commission on Nature and Agriculture issued a report (Commission on Nature and Agriculture, 2013 ) that recommended that nitrogen $(N)$ regulations should be adapted locally in future and, if possible, at field scale. As an integrated part of such a policy, there is a need to develop tools to identify fields that are vulnerable or non-vulnerable to nitrate leaching.

$\mathrm{N}$ is an essential plant nutrient, which is why $\mathrm{N}$-application to agricultural land is essential for sustaining food and fibre production for a rapidly growing population. The agricultural sector, however, has been identified as the largest 
nonpoint source contributor of nitrate to surface and groundwater bodies (Bakhsh et al., 2004; Beaudoin et al., 2005; Billy et al., 2011). The effects of agriculture may extend beyond the boundaries of fields or farms since the drainage systems will inevitably affect the flow pathways of water away from agricultural land and into the receiving water bodies (Robinson and Rycroft, 1999). However, the nonpoint loss of $\mathrm{N}$ from agricultural fields is controlled by an array of factors such as soil properties (physical, chemical and biological), climatic factors (precipitation and temperature patterns), farming practices (cropping system, fertilisation and tillage) and hydrology (Billy et al., 2011; Dinnes et al., 2002). Thus, high doses of $\mathrm{N}$ fertilisers may increase the $\mathrm{N}$-transport to drainage, especially when there is no further crop response (Delin and Stenberg, 2014). Crop response by catch crops in intensive agriculture in northern France has reduced the mean concentration by $50 \%$ on an annual scale (Beaudoin et al., 2005) and a winter cover of mustard has reduced the nitrate-N concentrations in temperate soils (Premrov et al., 2014).

The installation of tile drains is a common agricultural water management practice for improving moisture and aeration conditions (Tiemeyer et al., 2010; Van Der Ploeg et al., 1999) in areas with shallow groundwater and seasonally perched groundwater tables. The presence of tile drains enhances crop yields on soils, which are highly productive and poorly naturally drained, and helps reduce year-on-year variability in yields (Nangia et al., 2010) by promoting earlier sowing and improving traffic ability. The drains remove water from the land more quickly than under natural conditions and increase infiltration and deliver shallow groundwater more quickly to surface water, preventing its recharge to groundwater. This artificial drainage modifies $\mathrm{N}$-dynamics by facilitating the rapid transport of nitrate- $\mathrm{N}$ and greatly reducing or even suppressing the water residence time within natural retention zones. However, tile drain systems not only remove excess water from the root zone, but also facilitate $\mathrm{N}$-transport, primarily as soluble nitrate- $\mathrm{N}$, from the bottom of the root zone to the edge of the field (Billy et al., 2011; Mulla and Strock, 2008) and to surface water (Cordeiro et al., 2014; Eidem et al., 1999; Gilliam et al., 1979; Lapen et al., 2008). They also contribute to hypoxia (Billy et al., 2011). Drainage increases N-losses from agricultural areas as compared to former undrained fields. In addition, no biogeochemical processes such as denitrification are known to occur in buried pipes, which are considered inert pathways (Billy et al., 2013; Gilliam et al., 1999) whereas denitrification processes may be common at temperatures above approximately $5^{\circ} \mathrm{C}$ in the root zone with renewable source of bioavailable organic matter and restricted access of oxygen due to high water saturation or high microbial activity (Christensen et al., 1990; Ernstsen et al., 1998). Drainage decreases the possibilities of nitrate being denitrified or adsorbed by plants on-field (Gilliam et al., 1999) and off-field, the temperature-drainage signatures are crucial for denitrifi- cation in natural and constructed wetlands. Therefore the loss of nitrate-N leaching from the root zone is not solely an environmental concern, but also an economic loss to farmers (Schjonning et al., 2013).

The greatest intensity of drainage in Europe is concentrated in the northern areas around the Baltic and North Seas. This is largely due to climatic conditions and the presence of glacially derived clayey tills that can cause prolonged waterlogging (Robinson and Rycroft, 1999). Since around 1850, $50 \%$ of agricultural land in Denmark has been systematically tile drained, with horizontal spacing of 8-20 m (Olesen, 2009) and a total length of around $750000 \mathrm{~km}$ (BreuningMadsen, 2010).

A number of factors may affect the loss of nitrate- $\mathrm{N}$ from fields via drainage. The local climate (temperature and precipitation), soil type, crop type, length of growing season, options of winter cover crops and catch crops, tillage and soil management are also important factors in the concentration and leaching of nitrate-N from the root zone. Some of these factors are field specific and cannot be changed, e.g. the nitrate uptake of field crops is highly variable in the course of a year and between crops as the $\mathrm{N}$ uptake and growth stage are very complex (Gastal and Lemaire, 2002), whereas other factors may be adjusted to minimise the $\mathrm{N}$-loss for the benefit of the environment and farmers' incomes.

To the authors' knowledge, there has been limited documentation of nitrate- $\mathrm{N}$ concentrations and leaching via tile drain systems from field-size areas that have been monitored over a long period. In Denmark, data exist on nitrate$\mathrm{N}$ concentrations and leaching from a few short-term localscale studies (Bennetzen, 1978; Hansen and Pedersen, 1975; Pedersen, 1983; Simmelsgaard, 1998; Simmelsgaard and Djurhuus, 1998). Common among these studies is that there is no knowledge of the specific field contribution of nitrate$\mathrm{N}$ to drainage because the extent of the field's tile drain system is unknown or because there are different fields with different crops contributing to the drainage. To go from field scale to catchment scale, smaller-scale monitoring is important to provide an understanding of the ways in which fieldscale processes influence catchment-scale discharge and water quality (Rozemeijer et al., 2010; van der Velde et al., 2010).

To be able to optimise the use of $\mathrm{N}$ in agriculture and minimise nitrate leaching to the aquatic environment, it is imperative to be able to identify a field's natural ability to reduce nitrate. The aim of this study was twofold: (i) to provide detailed field-scale insight with regard to the impact of inherent conditions (air temperature, precipitation, and hydrogeological setting) and management (type of crops, crop development, amount and source of $\mathrm{N}$, and time for application of $\mathrm{N}$ fertilisers) on nitrate transport to drainage obtained from long-term monitoring in three agricultural clayey till fields exposed to different climatic conditions; and (ii) to elaborate on the impact of such detailed insight on future $\mathrm{N}$ regulation and $\mathrm{N}$ management on-field and off-field. 
Table 1. Precipitation $(P)$, evaporation $(E)$, drainage $(D)$, and groundwater discharge $(G)$ for the agrohydrological year (JuneJune) for 2001-2012 for the Faardrup, Silstrup and Estrup fields.

\begin{tabular}{lrrrrrrrr}
\hline Field & $P$ & $E$ & $D$ & $G$ & $D+G$ & & $D /(D+G)$ & $D / P$ \\
\cline { 2 - 4 } \cline { 7 - 9 } & \multicolumn{9}{c}{$\mathrm{mm} \mathrm{yr}^{-1}$} & & \multicolumn{2}{c}{$\%$} \\
\hline Faardrup & 685 & 459 & 95 & 131 & 226 & & 43 & 13 \\
Silstrup & 943 & 472 & 188 & 283 & 471 & & 40 & 20 \\
Estrup & 1089 & 476 & 421 & 196 & 617 & & 68 & 39 \\
\hline
\end{tabular}

\section{Material and methods}

\subsection{Field descriptions}

Three fields (Faardrup, Silstrup and Estrup) were selected to cover different types of clayey geological settings and climates, primarily expressed by the amount of annual precipitation (Fig. 1). The study sites are representative for about $71 \%$ of the clayey surface sediments in Denmark, with Faardrup representing 30\%, Silstrup also $30 \%$ and Estrup $11 \%$ (Barlebo et al., 2007). A summary of the main characteristics of each field is provided in Tables 1 and 2 (Lindhardt et al., 2001; Rosenbom et al., 2015).

The three fields (1.3-2.3 ha) are located on clay till plains with a small slope (0-3\%). The clayey till plain at Faardrup is homogenous, the clayey till plain at Silstrup comprises dislocated Oligocene clay, and at Estrup there is a complex structure with deposits of different ages and compositions. At Faardrup and Silstrup, located on sediments from the Late Weichselian age (about $15000 \mathrm{yr}$ BP), moderately welldrained Argiudoll was mapped with Hapludoll (Silstrup) and both Hapludoll and Vermudoll (Faardrup). Estrup is located on older sediments deposited under the Saalian glaciation (about $100000 \mathrm{yr}$ BP) with Argiudoll and Glossudalf (Table 2).

The content of organic matter in the surface layer disturbed by cultivation (Ap-horizon) was lowest $\left(1.4-1.5 \% \mathrm{C}^{-1}\right)$ in Faardrup, medium in Silstrup (1.6-2.0\% $\left.\mathrm{C}^{-1}\right)$, and highest $\left(1.6-3.2 \% \mathrm{C}^{-1}\right)$ in Estrup. In all fields, the C-contents decreased markedly at depths just below the Ap-horizon to contents of 0.06 to $0.8 \% \mathrm{C}^{-1}$. The clay content in the upper $0.2 \mathrm{~m}$ (Ap horizon) was $10-27 \%$ and varied to $6 \mathrm{~m}$ below the surface at between 1-65\% due to the heterogeneity of the clayey till. Postglacial leaching processes have formed an upper calcium-free zone about $1 \mathrm{~m}$ thick in the youngest sediments of Faardrup and Silstrup and down to 1 to $4 \mathrm{~m}$ at Estrup, due to the much longer ongoing weathering processes. In the calcareous zone below, the $\mathrm{CaCO}_{3}$ content varied between 21 and $82 \%$ in all three fields.

Subsurface tile drains were installed in the fields between the 1940s and 1960s. The drains were established at a depth of approximately $1.1 \mathrm{~m}$ with a horizontal spacing of $10-20 \mathrm{~m}$. Before monitoring began, the fields' tile drain system was isolated from the surrounding tile drain systems to ensure

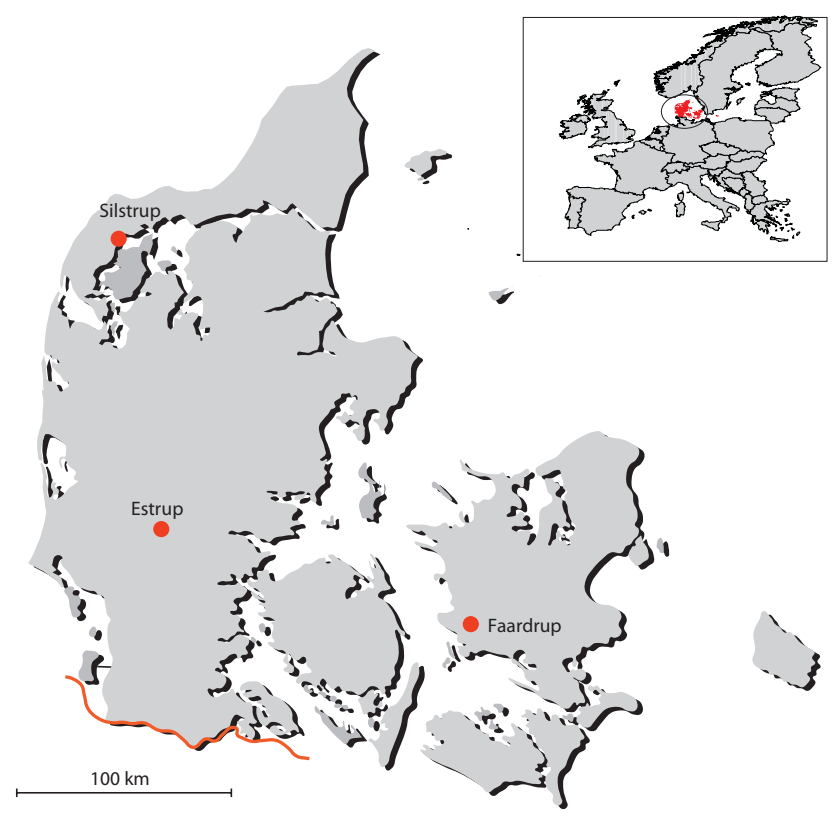

Figure 1. Map of Denmark showing the three clayey till fields: Faardrup, Silstrup and Estrup (Lindhardt et al., 2001).

that drainage only came from the fields. Any modifications were made outside the monitoring fields (Lindhardt et al., 2001).

\subsection{Farming practices}

The farming practices for the fields were in line with conventional practices in the different regions and with the application of nitrogen as recommended as good management practice in Denmark. In 2001-2011, crops of spring barley and winter wheat were the most common types in rotation with spring or winter rape, fodder or sugar beets and maize in all the fields. No catch crop has been grown in any of the fields. Red fescue for grass seed production was grown in Faardrup and Silstrup, as well as peas in Silstrup and Estrup. Each year, the amount of $\mathrm{N}$ fertilisers applied was adjusted to suit the selected crop type and the previous year's climatic conditions. As an average for 2001-2011, the annual $\mathrm{N}$-application was $136 \mathrm{~kg} \mathrm{Nha}^{-1} \mathrm{yr}^{-1}$ at Faardrup, $139 \mathrm{~kg} \mathrm{~N} \mathrm{ha}^{-1} \mathrm{yr}^{-1}$ at Silstrup, and $142 \mathrm{~kg} \mathrm{~N} \mathrm{ha}^{-1} \mathrm{yr}^{-1}$ at Estrup (Table 3). There were considerable differences in the average annual $\mathrm{N}$-application, ranging from $0 \mathrm{~kg} \mathrm{Nha}^{-1} \mathrm{yr}^{-1}$ for the pea crop to $223 \mathrm{~kg} \mathrm{Nha}^{-1} \mathrm{yr}^{-1}$ for spring barley undersown with red fescue. At Faardrup only inorganic N fertilisers were used, whereas at Silstrup and Estrup animal slurry was applied from time to time (Table 3). 
Table 2. Key parameters for the three fields according to Lindhardt et al. (2001) and Rosenbom et al. (2015).

\begin{tabular}{llll}
\hline Field & Faardrup & Silstrup & Estrup \\
\hline Size of field (ha) & 2.3 & 1.7 & 1.3 \\
Slope (\%) & $1-3$ & $1-2$ & $0-1$ \\
Soil type (USDA) & Argiudoll & Argiudoll & Argiudoll \\
& Hapludoll & Hapludoll & Glossudalf \\
& Vermudoll & & \\
Drainage status & Moderately & Moderately & Moderately \\
& well drained & well drained & well drained \\
Depth of tile drains $(\mathrm{m})$ & 1.1 & 1.1 & 1.1 \\
C in Ap $(0-0.2 \mathrm{~m})(\%)$ & $1.4-1.5$ & $1.6-2.0$ & $1.6-3.2$ \\
C below Ap $(0.2-6 \mathrm{~m})(\%)$ & $0.06-0.23$ & $0.06-2.1$ & $0.1-50$ \\
Clay in Ap $(0-0.2 \mathrm{~m})(\%)$ & $15-16$ & $18-27$ & $10-20$ \\
Clay below Ap $(0.2-6 \mathrm{~m})(\%)$ & $16-37$ & $18-58$ & $1-65$ \\
Depth to calcareous zone $(\mathrm{m})$ & 1.5 & 1.1 & $1-4$ \\
CaCO $(\%)(0-6 \mathrm{~m})$ & $0-21$ & $0-46$ & $0-82$ \\
Age of sediments & Late Weichselian & Late Weichselian & Saalian \\
& glaciation & glaciation & glaciation \\
Landscape & Till plain & Till plain & Till plain \\
Geology & Homogenous & Dislocated & Complex \\
& & structure & structure \\
\hline
\end{tabular}

Table 3. Annual average of minimum, mean, and maximum air temperatures for 2001-2012 at Faardrup, Silstrup and Estrup.

\begin{tabular}{lrrr}
\hline Temperature & Faardrup & Silstrup & Estrup \\
\hline Average minimum air temperature $\left({ }^{\circ} \mathrm{C}\right)$ & 5.6 & 6.0 & 5.8 \\
Minimum air temperature $\left({ }^{\circ} \mathrm{C}\right)$ & -19.5 & -14.5 & -15.7 \\
Average maximum air temperature $\left({ }^{\circ} \mathrm{C}\right)$ & 12.0 & 11.4 & 12.2 \\
Maximum air temperature $\left({ }^{\circ} \mathrm{C}\right)$ & 31.3 & 30.4 & 32.1 \\
Average mean air temperature $\left({ }^{\circ} \mathrm{C}\right)$ & 8.8 & 8.7 & 9.0
\end{tabular}

\subsection{Monitoring setup}

The specific growth stages for the different crops were characterized using the BBCH scale (Meier, 2001), e.g. the $\mathrm{BBCH}$ growth stages for cereals: germination (00-09), leaf development (10-19), tillering (20-29), steam elongation (30-49), inflorescence emergence (51-59), flowering (61-69), development of fruit (71-77), ripening (8389), and senescence (92-99) (Meier, 2001). Precipitation was measured on site and air temperature was recorded at nearby meteorological stations. The water table was registered in piezometers constructed of $6.3 \mathrm{~cm}$ diameter polyvinyl chloride with $0.5 \mathrm{~m}$ screens placed at depths of 3.0-3.5, 4.55.0, and $6.1-6.6 \mathrm{~m}$ at the edge of the Faardrup, Estrup, and Silstrup fields. Daily monitoring of the water table at Silstrup and Estrup was performed using a D-Diver (Van Essen Instruments, Delft, The Netherlands) and monthly monitoring of the water table at Faardrup was performed with a hand-held water level meter, type 010 (HT Hydrotechnik, Obergünzburg, Germany). ISCO samplers (Teledyne ISCO, Lincoln, NE, USA) were used to collect samples of drainage water. Drainage water was sampled time proportionally until July 2004 and then flow proportionally, with sub-samples collected for every $3000 \mathrm{~L}$ of drainage during the winter season (September-May) and for every $1500 \mathrm{~L}$ during the summer season (June-August). Each week, all the collected subsamples were pooled and a sample was analysed in the laboratory.

\subsection{Nitrate-N analysis}

Samples of drainage were refrigerated at all times until analysis. The water samples were $0.45 \mu \mathrm{m}$ filtrated (Millex HV syringe filter, Millipore, Ireland) and nitrate- $\mathrm{N}\left(\mathrm{NO}_{3}-\mathrm{N}\right)$ was measured using a Metrohm Anion system equipped with a Metrosep A Supp 15-250 IC column and a suppressor module (MSM) and with conductivity detection (Mehrohm, Herisau, Switzerland). The eluent was a mixture of $1 \mathrm{mM}$ $\mathrm{NaHCO}_{3}$ and $3.2 \mathrm{mM} \mathrm{Na} \mathrm{CO}_{3}$. The system was connected to an 838 Advanced IC Sample processer (Mehrohm, Herisau, Switzerland).

\subsection{Calculation of $\mathrm{N}$-flux in drainage}

The total mass of nitrate- $\mathrm{N}$ transported out of the field by drainage was calculated by multiplying the concentration of nitrate- $\mathrm{N}$ for the pooled water sampled by the drainage volume between the time of sampling and the previous time of sampling. The nitrate-N losses were all calculated as $\mathrm{kg} \mathrm{N} \mathrm{ha}^{-1}$, taking into account the different sizes of the three fields. 

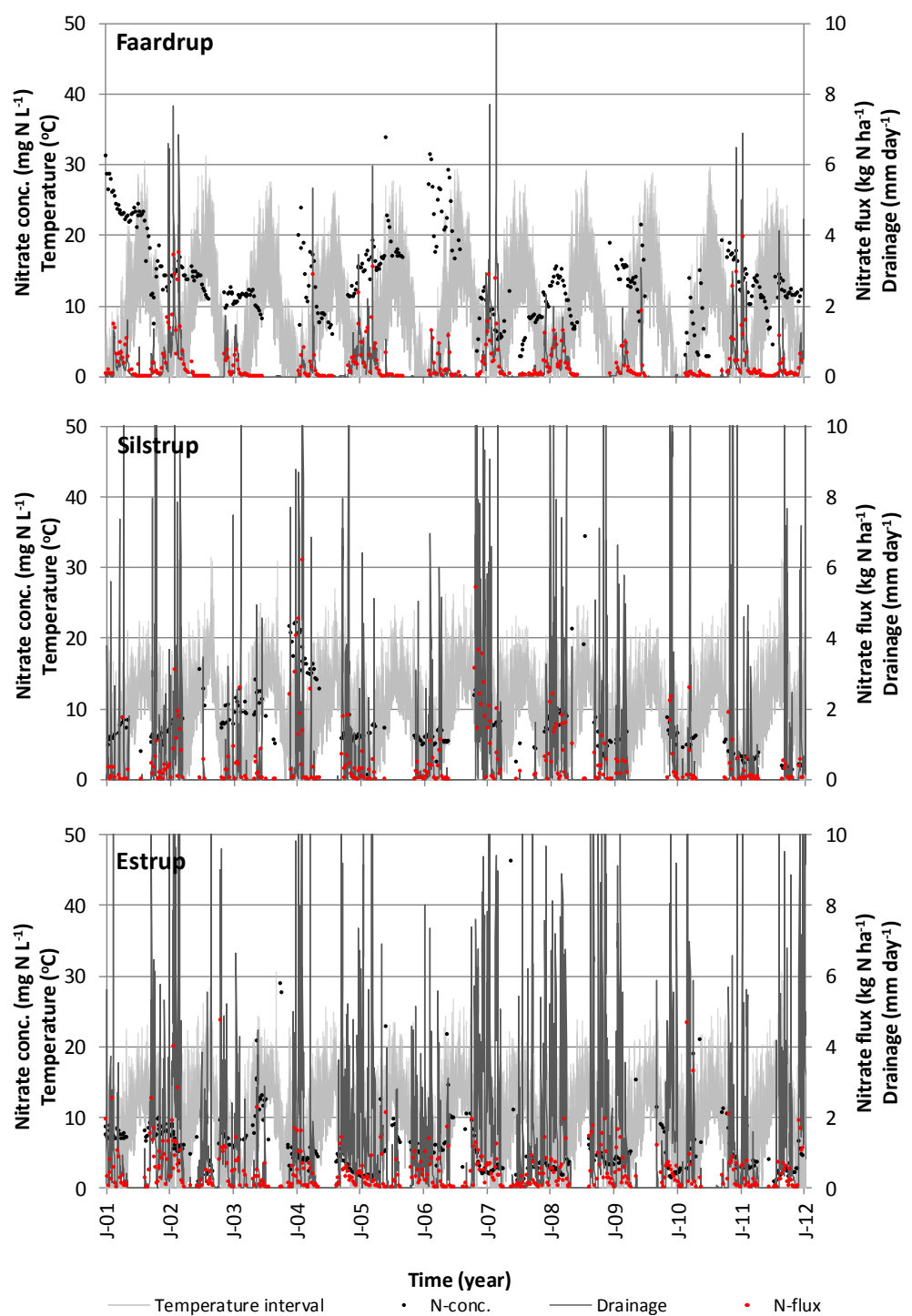

Figure 2. Concentration of nitrate-N, nitrate- $\mathrm{N}$ fluxes, drainage and the daily minimum-maximum temperature span for temperatures above zero degrees Celsius for 2001-2012 at Faardrup, Silstrup and Estrup.

\section{Results}

\subsection{Climate}

All three fields are located in a temperate climate with average air temperatures between 8.8 and $9.0^{\circ} \mathrm{C}$ for $2001-$ 2011. During monitoring, the minimum (yearly) average temperatures were $5.6-5.8^{\circ} \mathrm{C}$ and the maximum (yearly) average temperatures were $11.4-12.2^{\circ} \mathrm{C}$, with summer temperatures up to $30.4-32.1^{\circ} \mathrm{C}$ and winter temperatures down to -14.1 and $-19.5^{\circ} \mathrm{C}$ (Fig. 2 and Table 4). The geographical location of the fields led to differences in annual precipitation. Average annual precipitation between 2001 and 2012 was $685 \mathrm{~mm}$ at Faardrup and $943 \mathrm{~mm}$ at Silstrup, with the highest being Estrup at $1089 \mathrm{~mm}$ (Table 1). As the fields' average annual evaporation only varied slightly (be- tween 459 and $476 \mathrm{~mm}$ ), the annual leaching to drainage and groundwater was $226 \mathrm{~mm}$ at Faardrup, $471 \mathrm{~mm}$ at Silstrup, and $617 \mathrm{~mm}$ at Estrup (Table 1).

In 2001-2012, 49, 16, and 3.3\% of drainage at Faardrup were on days on which air temperatures were above 5, 10 and $15^{\circ} \mathrm{C}$, respectively (Fig. 2 and Table 5). At Silstrup 56, 12, and $0.3 \%$ and at Estrup 58, 22, and $5.4 \%$ of drainage occurred in the respective temperature categories (Fig. 2 and Table 5).

\subsection{Hydrogeological setting}

At Faardrup, monthly registration of the groundwater table at the edge of the field showed the overall pattern over the year, even though its full amplitude was not monitored as the filter had not been installed sufficiently deep to register 

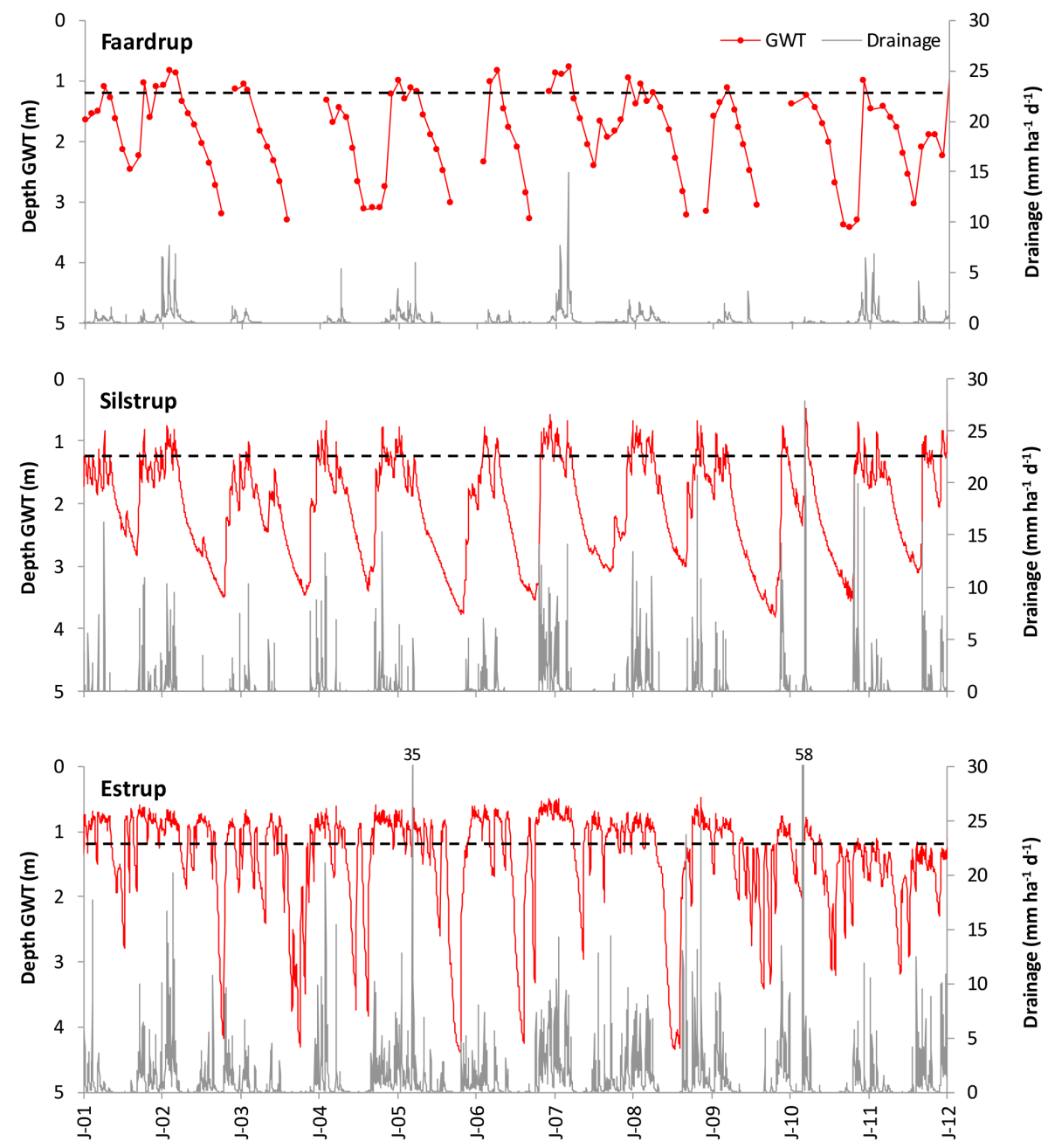

Figure 3. Drainage and depth to groundwater table (GWT) in 2001-2012 at Faardrup, Silstrup and Estrup. The black dashed lines indicate tile drain depth.

deepest water tables (Fig. 3). The water table approached the soil surface by the end of autumn and during winter, and dropped in spring, summer and early autumn to about $3.5 \mathrm{~m}$ depth or even deeper. During 2001-2012, the average daily drainage was $0.26 \mathrm{~mm} \mathrm{~d}^{-1}$ and max daily drainage was $14.9 \mathrm{~mm} \mathrm{~d}^{-1}$ during an average 88 days of drainage per year (Table 5). Typically, drainage was below $3 \mathrm{~mm} \mathrm{~d}^{-1}$ and rarely above $10 \mathrm{~mm} \mathrm{~d}^{-1}$ (Fig. 3). For 2001-2012, the average annual drainage was $43 \%$ of total discharge to drainage plus groundwater (Table 1).

At Silstrup, the groundwater table was above drainage depth from late autumn to late winter and dropped during spring and summer to a depth of $3.82 \mathrm{~m}$ at its lowest (October 2009) (Fig. 3). During 2001-2011, the average daily drainage was $0.50 \mathrm{~mm} \mathrm{~d}^{-1}$ and max daily drainage was $27.8 \mathrm{~mm} \mathrm{~d}^{-1}$ during an average of 86 days of drainage (Table 5). Often, the drainage events were above $5 \mathrm{~mm} \mathrm{~d}^{-1}$, a few were up to $10 \mathrm{~mm} \mathrm{~d}^{-1}$, with a maximum drainage of
$28 \mathrm{~mm} \mathrm{~d}^{-1}$ in March 2010 (Fig. 3). For 2001-2012 the average annual drainage was $40 \%$ of total discharge to drainage plus groundwater (Table 1).

In Estrup, the groundwater table was highly dynamic and only located deeply for short periods. The lowest groundwater table ( $4.35 \mathrm{~m}$ ) was in July 2008 (Fig. 3). On average for 2001-2012, the average daily drainage was $1.16 \mathrm{~mm} \mathrm{~d}^{-1}$ and max daily drainage was $57.8 \mathrm{~mm} \mathrm{~d}^{-1}$ during an annual average 243 days of drainage (Table 5). Daily drainage was often above $5-6 \mathrm{~mm} \mathrm{~d}^{-1}$, in some cases up to $10 \mathrm{~mm} \mathrm{~d}^{-1}$, and the highest amounts registered were $35 \mathrm{~mm} \mathrm{~d}^{-1}$ in March 2005 and $58 \mathrm{~mm} \mathrm{~d}^{-1}$ in February 2010 (Fig. 3). For 2001-2012 the average annual drainage was $68 \%$ of total discharge to drainage plus groundwater (Table 1).

\subsection{Management $-\mathbf{N}$ fertilisers and crop types}

The time of application and amount of $\mathrm{N}$ fertilisers applied to the crops were in line with present legislation (concern- 


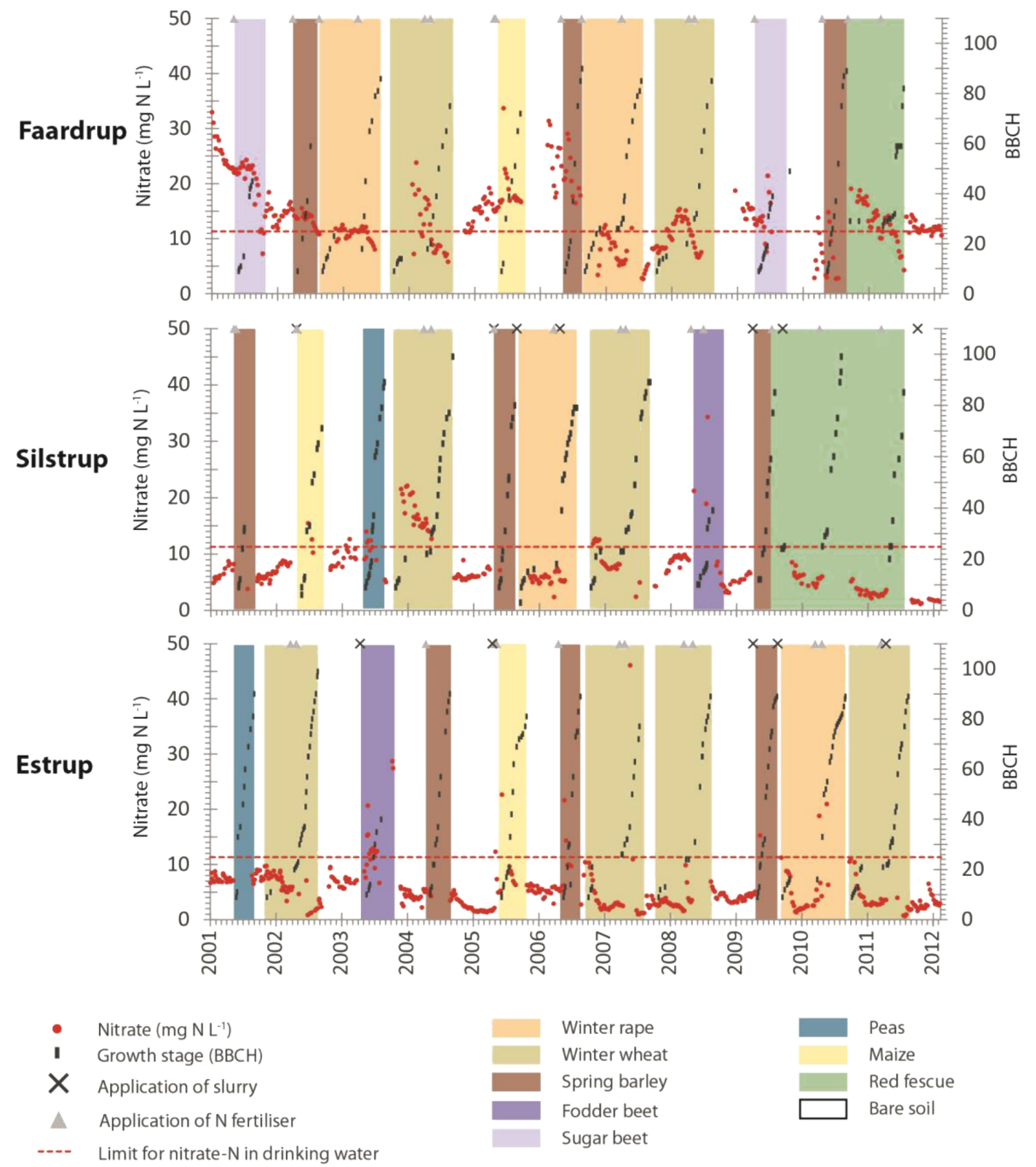

Figure 4. Crop type, specific growth stage of crops according to the $\mathrm{BBCH}$ scale, application of inorganic $\mathrm{N}$ fertiliser and injection of slurry

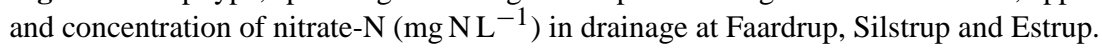

ing application of slurry) and the type of crop (concerning application of slurry and inorganic $\mathrm{N}$ fertiliser) (Ministry of Food, Agriculture and Fisheries, The Danish AgriFish Agency, http://agrifish.dk/).

At the Faardrup field only inorganic $\mathrm{N}$ fertiliser was used (Table 3). The time of application for the different crops is indicated in Fig. 4. For sugar beet, spring barley and maize, $\mathrm{N}$ fertiliser was applied immediately before or after sowing. $\mathrm{N}$ fertiliser was applied twice during the growing season for winter cover crops: for winter wheat the first occasion was at about growth stage BBCH 12-26 and the second occasion was at about $\mathrm{BBCH}$ stage 23-32, while for winter rape it was at around sowing time and at growth stage 14-37. The red fescue received small amounts of fertiliser just after the spring barley was harvested and at the beginning of the growing season. The application of $\mathrm{N}$ fertilisers was not reflected in simultaneous/subsequent increases in nitrate- $\mathrm{N}$ concentra- tions in the drainage. A total of 16 applications of $\mathrm{N}$ were performed.

The time of $\mathrm{N}$-application at Silstrup was as described for Faardrup. A crop of pea in 2001 received no $\mathrm{N}$ fertilisation (Table 3 and Fig. 4). At Silstrup, inorganic N fertiliser, injected slurry (pig/cattle) or a combination of inorganic $\mathrm{N}$ fertiliser and slurry were applied to the crops. Application took place at BBCH stage 20-30 for both winter wheat (2004 and 2007) and red fescue (2010 and 2011). In 2001-2012, the application of inorganic $\mathrm{N}$ fertiliser (in total 13 times) and slurry (in total seven times) was not reflected in immediate increased $\mathrm{N}$-concentrations in the drainage, except for fodder beet in 2008 .

At Estrup, inorganic $\mathrm{N}$ fertiliser, injected slurry (cattle/sow/pig) or a combination of the two was applied to all the crops except the pea crop (Table 3 and Fig. 4). Application of fertilisers was performed at $\mathrm{BBCH} 20-30$ for winter wheat 
Table 4. Crops and winter cover crops (in bold), crop rotation, types of N-source (F: inorganic fertilisers; C: cattle manure, S: sow manure and P: pig manure), and the amount of $\mathrm{N}$ fertilisers $\left(\mathrm{kg} \mathrm{N} \mathrm{ha}^{-1} \mathrm{yr}^{-1}\right)$ applied in 2001-2012 at Faardrup, Silstrup and Estrup.

\begin{tabular}{|c|c|c|c|c|c|c|c|c|c|}
\hline \multirow[t]{2}{*}{ Year } & \multicolumn{3}{|c|}{ Faardrup } & \multicolumn{3}{|c|}{ Silstrup } & \multicolumn{3}{|c|}{ Estrup } \\
\hline & Crop & Source & $\begin{array}{r}\text { Dose } \\
\mathrm{kg} \mathrm{N} \mathrm{ha}^{-1} \mathrm{yr}^{-1}\end{array}$ & Crop & Source & $\begin{array}{r}\text { Dose } \\
\mathrm{kg} \mathrm{Nha}^{-1} \mathrm{yr}^{-1}\end{array}$ & Crop & Source & $\begin{array}{r}\text { Dose } \\
\mathrm{kg} \mathrm{Nha}^{-1} \mathrm{yr}^{-1}\end{array}$ \\
\hline 2001 & Sugar beet & $\mathrm{F}$ & 110 & Spring barley & $\mathrm{F}$ & 118 & $\begin{array}{l}\text { Peas } \\
\text { Winter wheat }\end{array}$ & - & 0 \\
\hline 2002 & $\begin{array}{l}\text { Spring barley } \\
\text { Winter rape }\end{array}$ & $\mathrm{F}$ & 125 & Maize & $\mathrm{F}, \mathrm{C}$ & 163 & Winter wheat & $\mathrm{F}$ & 147 \\
\hline 2003 & $\begin{array}{l}\text { Winter rape } \\
\text { Winter wheat }\end{array}$ & $\mathrm{F}$ & 145 & $\begin{array}{l}\text { Peas } \\
\text { Winter wheat }\end{array}$ & - & 0 & Fodder beet & $\mathrm{C}$ & 169 \\
\hline 2004 & Winter wheat & $\mathrm{F}$ & 154 & Winter wheat & $\mathrm{F}$ & 170 & Spring barley & $\mathrm{F}$ & 105 \\
\hline 2005 & Maize & $\mathrm{F}$ & 129 & $\begin{array}{l}\text { Spring barley } \\
\text { Winter rape }\end{array}$ & $\mathrm{F}, \mathrm{P}$ & 167 & Maize & F, S & 164 \\
\hline 2006 & $\begin{array}{l}\text { Spring barley } \\
\text { Winter rape }\end{array}$ & $\mathrm{F}$ & 130 & $\begin{array}{l}\text { Winter rape } \\
\text { Winter wheat }\end{array}$ & F, P & 96 & $\begin{array}{l}\text { Spring barley } \\
\text { Winter wheat }\end{array}$ & $\mathrm{F}$ & 112 \\
\hline 2007 & $\begin{array}{l}\text { Winter rape } \\
\text { Winter wheat }\end{array}$ & $\mathrm{F}$ & 151 & Winter wheat & $\mathrm{F}$ & 162 & $\begin{array}{l}\text { Winter wheat } \\
\text { Winter wheat }\end{array}$ & $\mathrm{F}$ & 178 \\
\hline 2008 & Winter wheat & $\mathrm{F}$ & 156 & Fodder beet & $\mathrm{F}$ & 244 & Winter wheat & $\mathrm{F}$ & 180 \\
\hline 2009 & Sugar beet & $\mathrm{F}$ & 110 & $\begin{array}{l}\text { Spring barley } \\
\text { Red fescue }\end{array}$ & $\mathrm{F}, \mathrm{P}$ & 223 & $\begin{array}{l}\text { Spring barley } \\
\text { Winter wheat }\end{array}$ & $\mathrm{P}, \mathrm{S}$ & 167 \\
\hline 2010 & $\begin{array}{l}\text { Spring barley } \\
\text { Red fescue }\end{array}$ & $\mathrm{F}$ & 179 & Red fescue & $\mathrm{F}$ & 58 & $\begin{array}{l}\text { Winter rape } \\
\text { Winter wheat }\end{array}$ & $\mathrm{F}$ & 181 \\
\hline 2011 & Red fescue & $\mathrm{F}$ & 104 & Red fescue & F, P & 123 & Winter wheat & F, S & 160 \\
\hline Total & & & 1493 & & & 1524 & & & 1563 \\
\hline $\begin{array}{l}\text { Yearly } \\
\text { average }\end{array}$ & & & 136 & & & 139 & & & 142 \\
\hline
\end{tabular}

Table 5. Minimum (min.), maximum (max.) and average (avg.) daily drainage, average annual number of days with drainage, average air temperatures during drainage, and cumulated drainage, all 2001-2012 at Faardrup, Silstrup and Estrup.

\begin{tabular}{|c|c|c|c|c|c|c|c|c|c|}
\hline \multirow[t]{3}{*}{ Field } & \multicolumn{4}{|c|}{ Drainage } & \multicolumn{4}{|c|}{ Average air temperature $\left({ }^{\circ} \mathrm{C}\right)$} & \multirow{3}{*}{$\begin{array}{r}\text { Drainage } \\
2001-2011 \\
\mathrm{~mm}\end{array}$} \\
\hline & $\min$. & $\max$ & avg. & \multirow{2}{*}{$\begin{array}{r}\text { avg. } \\
\text { days } \mathrm{yr}^{-1}\end{array}$} & $<5$ & $\geq 5$ & $>10$ & $>15$ & \\
\hline & \multicolumn{3}{|c|}{$\mathrm{mm} \mathrm{d}^{-1}$} & & \multicolumn{4}{|c|}{$\%$ of cumulated drainage } & \\
\hline Faardrup & 0.1 & 14.9 & 0.26 & 88 & 51 & 49 & 16 & 3.3 & 961 \\
\hline Silstrup & 0.1 & 27.8 & 0.50 & 86 & 44 & 56 & 12 & 0.3 & 2304 \\
\hline Estrup & 0.1 & 57.8 & 1.16 & 243 & 42 & 58 & 22 & 5.4 & 4921 \\
\hline
\end{tabular}

and at about $\mathrm{BBCH} 30$ for winter rape. In total, inorganic $\mathrm{N}$ fertiliser and slurry were applied 12 times and seven times respectively. In seven of the 11 years (2003, 2005, 2006, 2007 , 2008, 2009 and 2010) the application of $\mathrm{N}$ fertilisers was reflected in short-term increases (maximum concentration of $47 \mathrm{mg} \mathrm{N} \mathrm{L}^{-1}$ in 2007) in drainage from the field.

\subsection{Nitrate concentrations}

In Faardrup, the nitrate- $\mathrm{N}$ concentrations in drainage were often well above the European limit for drinking water supply (11.3 $\mathrm{mg} \mathrm{N} \mathrm{L}^{-1}$ ) (Fig. 2). The drainage signature was characterised by a large range of nitrate- $\mathrm{N}$ concentrations (3$34 \mathrm{mg} \mathrm{N} \mathrm{L}^{-1}$ ). Prolonged high nitrate-N concentrations were measured below bare soil after harvesting winter wheat in 2000/2001, 2004/2005 and 2009, and after harvesting maize in 2006. Increasing nitrate-N concentrations were measured up to a BBCH growth stage of about 30 for winter rape (2002/2003, 2006/2007) and winter wheat (2007/2008). At later $\mathrm{BBCH}$ stages and up to harvest, nitrate- $\mathrm{N}$ concentrations decreased. Decreasing nitrate-N concentrations were also observed during the growing seasons of sugar beet (2001), spring barley $(2002,2006)$, maize (2005) and red fescue $(2010 / 2011)$. 

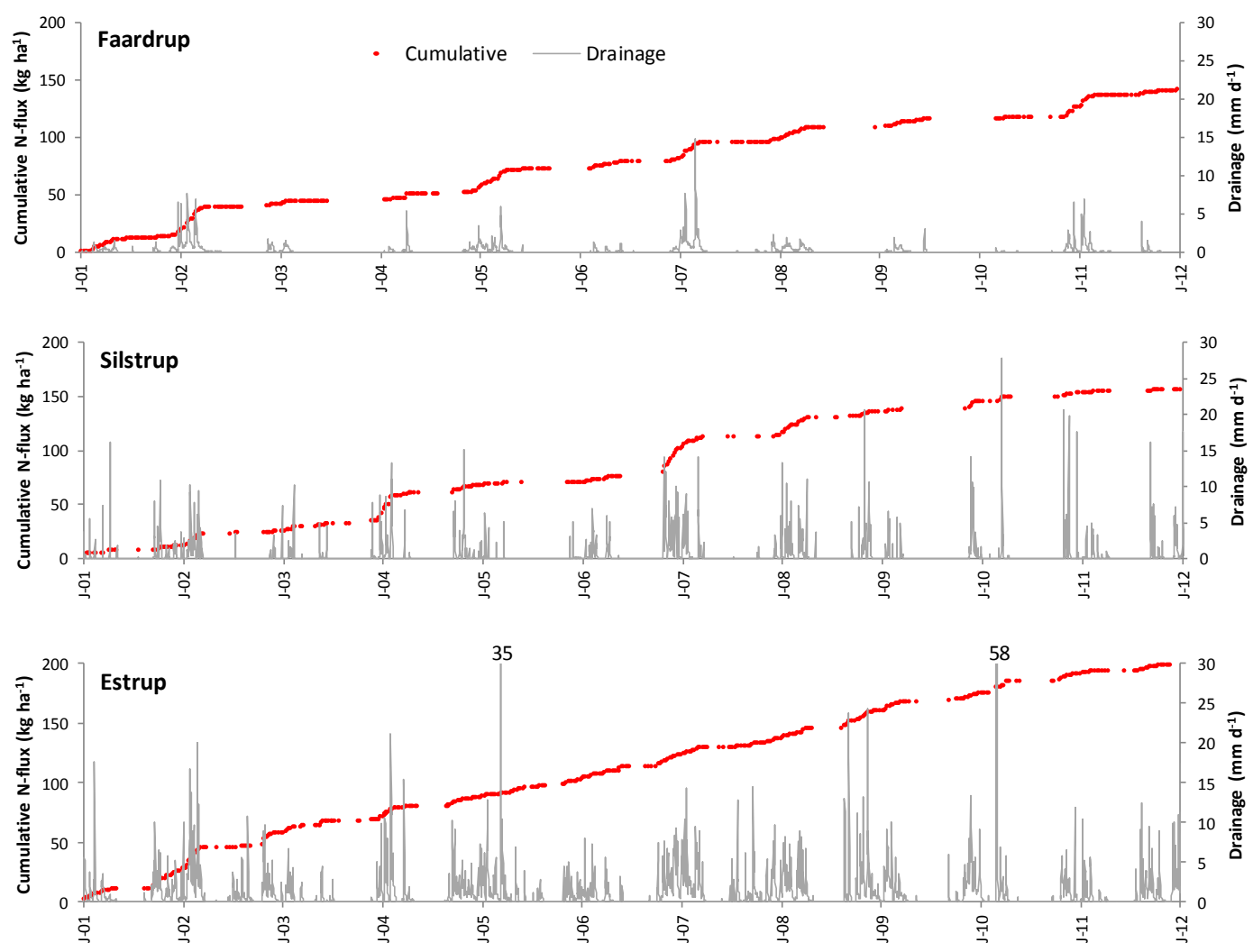

Figure 5. Cumulative nitrate-N flux and drainage for 2001-2012 at Faardrup, Silstrup and Estrup.

In 2001-2012, the nitrate- $\mathrm{N}$ concentrations in drainage at Silstrup varied between $1-34 \mathrm{mg} \mathrm{NL}^{-1}$ and rarely exceeded the European limit for drinking water (Fig. 2). Prolonged elevated nitrate- $\mathrm{N}$ concentrations were measured below bare soil after fodder beet (2000/2001, 2008/2009), spring barley (2001/2002), maize (2002/2003) and winter wheat $(2004 / 2005,2007 / 2008)$, whereas the nitrate-N concentrations in drainage after red fescue remained at a constant low level (1-2 $\mathrm{mg} \mathrm{NL}^{-1}$ ) (Fig. 2). Remarkably high (maximum $22 \mathrm{mg} \mathrm{N} \mathrm{L}^{-1}$ ) nitrate-N concentrations, well above the EU limit for drinking water, were recorded only following the winter wheat crop (2003/2004).

Except for some short-term peak concentrations, the Nconcentration in drainage at Estrup was below the EU limit for drinking water (Fig. 2). This also applied to the periods with bare soil, where the nitrate- $\mathrm{N}$ concentrations remained almost constant, except following spring barley (2004/2005) when concentrations decreased, and after winter wheat (2011/2012) when they increased. Concentrations of nitrate-N decreased during the growing seasons of fodder beet (2003), winter wheat (2007) and winter rape (2009).

\subsection{Nitrate-N fluxes}

At Faardrup, short-term N-leaching events, often in winter (or the start of the year), with daily fluxes of nitrate- $\mathrm{N}$ be- low $1 \mathrm{~kg} \mathrm{Nha}^{-1} \mathrm{~d}^{-1}$ were common (Fig. 2). Some leaching events were in the range of $0.5-1 \mathrm{~kg} \mathrm{Nha}^{-1} \mathrm{~d}^{-1}$ and very few events were in the range of $1-4 \mathrm{~kg} \mathrm{Nha}^{-1} \mathrm{~d}^{-1}$. The nitrateflux signature was highly related to the drainage events, as indicated by the step-like shape in 2002/2003, 2005 and 2011 (Fig. 5) and a good correlation $\left(R^{2}=0.83\right)$ between cumulated nitrate flux and drainage intensity in the time between water sampling (Fig. 6). In this field, annual nitrate fluxes varied between 3 and $24 \mathrm{~kg} \mathrm{Nha}^{-1} \mathrm{yr}^{-1}$ and made up the equivalent of $2-19 \%$ of the annual applied $\mathrm{N}$ fertilisers (Fig. 7). The total nitrate flux for 2001-2012 in drainage was $142 \mathrm{~kg} \mathrm{Nha}^{-1}$ and in this period $1493 \mathrm{~kg} \mathrm{~N} \mathrm{ha}^{-1}$ was applied as $\mathrm{N}$ fertilisers (Table 3).

Most nitrate-N leaching events in 2001-2012 at Silstrup took place during the autumn and winter, and often the daily fluxes were below $1 \mathrm{~kg} \mathrm{Nha}^{-1} \mathrm{~d}^{-1}$. Only a few were within the range of $1-2 \mathrm{~kg} \mathrm{Nha}^{-1} \mathrm{~d}^{-1}$ and were rarely above $2 \mathrm{~kg} \mathrm{Nha}^{-1} \mathrm{~d}^{-1}$ (Fig. 2). Large and lasting drainage (2002, 2004, 2006/2007, 2008 and 2009/2010) coincided with high $\mathrm{N}$-fluxes out of the field (Fig. 5), and increasing $\mathrm{N}$-fluxes with increasing drainage cumulated for the time interval between sampling $\left(R^{2}=0.60\right)$ (Fig. 6). The annual export of nitrate- $\mathrm{N}$ from the field with drainage varied between 3$32 \mathrm{~kg} \mathrm{Nha}^{-1} \mathrm{yr}^{-1}$, equivalent to $2-33 \%$ of the annual applied $\mathrm{N}$ fertilisers (inorganic $\mathrm{N}$ fertilisers and slurry) (Fig. 7). For the period 2001-2012 the total nitrate-N leaching from 

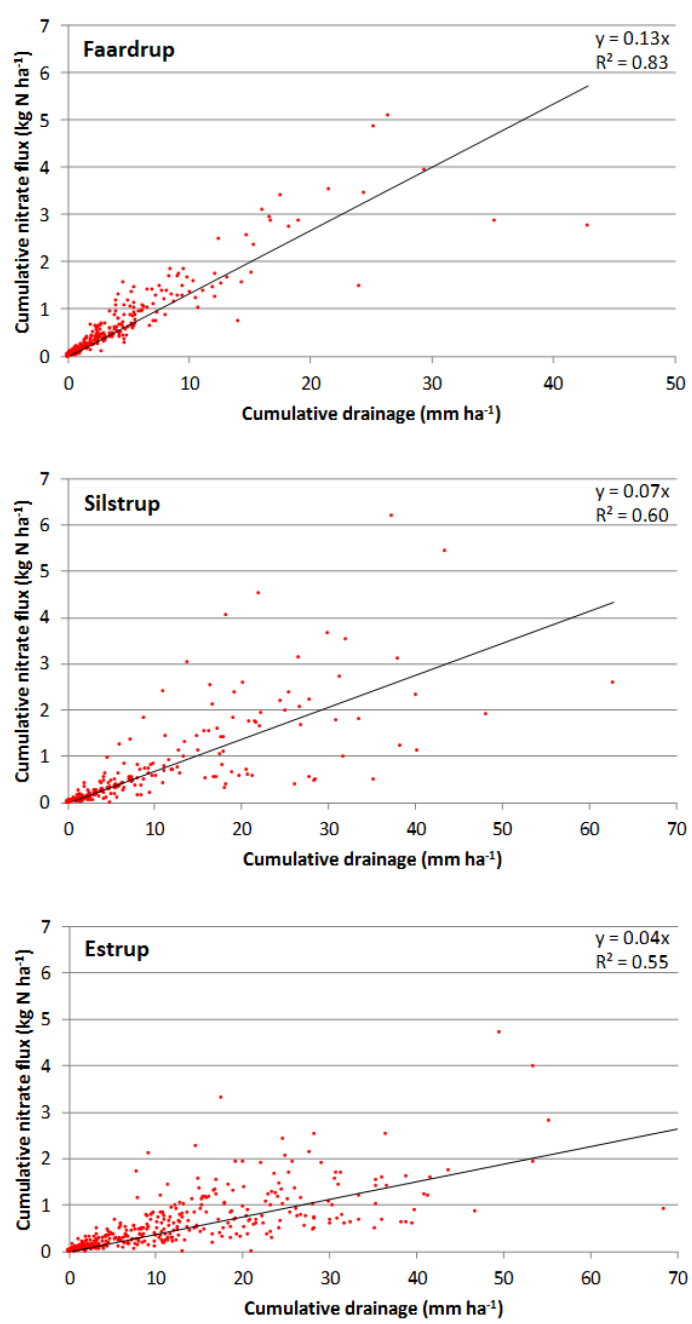

Figure 6. Nitrate-N flux per cumulated drainage for each sampling period at Faardrup, Silstrup and Estrup.

the field was $153 \mathrm{~kg} \mathrm{Nha}^{-1}$, as compared to the total application of $1524 \mathrm{~kg} \mathrm{Nha}^{-1}$ (Table 3).

Leaching from Estrup was present throughout the year, often with daily nitrate- $\mathrm{N}$ fluxes of below $1 \mathrm{~kg} \mathrm{Nha}^{-1} \mathrm{~d}^{-1}$, and only above $1 \mathrm{~kg} \mathrm{Nha}^{-1} \mathrm{~d}^{-1}$ during a few events (Fig. 2) and the correlation between the $\mathrm{N}$-fluxes and drainage, cumulated between sampling, was $R^{2}=0.55$ (Fig. 6). The drainage signature at Estrup, with a long drainage period and renewable pool of crop-generated available organic matter with low nitrate fluxes, made the cumulated N-leaching curve very smooth, with only a few small steps (Fig. 5). The annual nitrate-N leaching was $13-32 \mathrm{~kg} \mathrm{Nha}^{-1} \mathrm{yr}^{-1}$, the equivalent of $8-22 \%$ of the total amount of $\mathrm{N}$ applied to the field (Fig. 7). In 2001-2012 the total loss with drainage was $205 \mathrm{~kg} \mathrm{Nha}^{-1}$ and the total $\mathrm{N}$-application was $1563 \mathrm{~kg} \mathrm{~N} \mathrm{ha}^{-1}$ (Table 3).

\section{Discussion}

\subsection{Climate}

For 2001-2012, the average air temperature at the three fields was approximately the same $\left(8.8-9.0^{\circ} \mathrm{C}\right)$ throughout the years studied. The maximum temperatures $\left(30-32^{\circ} \mathrm{C}\right)$ were measured in June to August and the minimum $(-14.1$ to $-19.5^{\circ} \mathrm{C}$ ) in December to February. Even though the average air temperatures varied only slightly between the three fields, air temperature during drainage was markedly different. At Faardrup, an often late drainage resulted in $51 \%$ run-off at temperatures below $5^{\circ} \mathrm{C}$ (below biological zero) whereas at Silstrup and Estrup most drainage (56 and 58\%) was at temperatures above $5{ }^{\circ} \mathrm{C}$. At Estrup, with drainage taking place during about two-thirds of the year, $5.4 \%$ of drainage was at temperatures above $>15^{\circ} \mathrm{C}$. The fieldspecific temperature-drainage signature provides valuable input to future water management, including on-field and offfield $\mathrm{N}$ regulation.

The almost identical temperature regimes made evaporation vary only slightly between the three fields, and hence groundwater recharge was lowest in Faardrup where there was the least precipitation. The low groundwater recharge at Faardrup generated a higher concentration of nitrate- $\mathrm{N}$ in water leaving the root zone from the different crops and from bare soil than at the two other fields in Silstrup and Estrup. Due to the low recharge and despite Faardrup receiving the lowest total amount of $\mathrm{N}$ as well as in a form readily available to plants, concentrations of nitrate- $\mathrm{N}$ in drainage from this field remained highest. At Silstrup and Estrup, much higher precipitation managed to keep the average concentration of nitrate- $\mathrm{N}$ below the EU limit for drinking water.

\subsection{Hydrological setting}

The drainage signatures were significantly different at the three fields, with each representative of its own type due to the local climatic and hydrological conditions. At Faardrup, where there is low precipitation and recharge and a longlasting deeply located groundwater table, drainage runoff

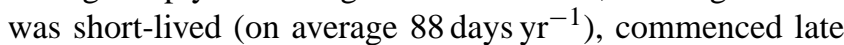
(middle of winter), was at the lowest air temperature (51\% at $<5^{\circ} \mathrm{C}$ ) and was of low intensity (average $0.26 \mathrm{~mm} \mathrm{~d}^{-1}$ ). Compared to the other two fields, Silstrup had a medium precipitation and discharge. The groundwater table was located deep for a long period of time, whereas drainage (on average 86 days $\mathrm{yr}^{-1}$ ) often started in autumn at higher temperatures $\left(56 \%\right.$ at $\left.>5^{\circ} \mathrm{C}\right)$, and was of a higher intensity (average $0.50 \mathrm{~mm} \mathrm{~d}^{-1}$ ). At Estrup, where there is the highest precipitation and recharge as well as a shallow and highly dynamic ground water table, drainage occurred most of the year (on average 243 days $\mathrm{yr}^{-1}$ ), and often at high intensity $\left(1.16 \mathrm{~mm} \mathrm{~d}^{-1}\right)$. The different drainage signatures also led to differences in the total nitrate- $\mathrm{N}$ 

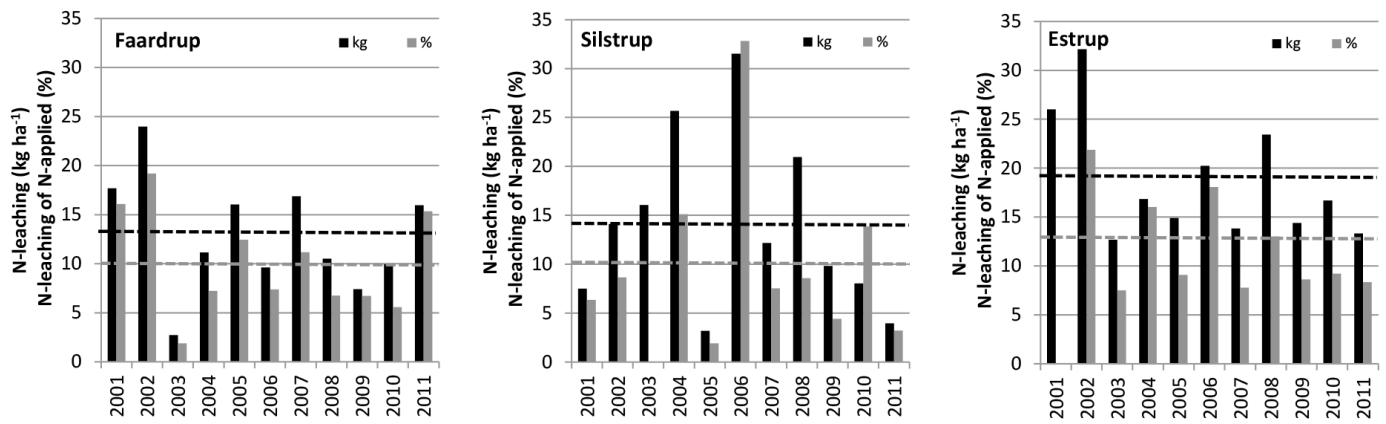

Figure 7. Nitrate-N in drainage in mass $\left(\mathrm{kg} \mathrm{Nha}^{-1}\right)$ and of applied $\mathrm{N}(\%)$ (inorganic $\mathrm{N}$ fertilisers plus slurry) for the years 2001 to 2011 at Faardrup, Silstrup and Estrup. The black dashed line indicates the average annual N-leaching in 2001-2012 and the grey dashed line is the average nitrate-N leaching of applied $\mathrm{N}$ in 2001-2012.

leaching for 2001-2012, with the least drainage leaching at Faardrup with $142 \mathrm{~kg} \mathrm{Nha}^{-1}$, medium leaching at Silstrup with $153 \mathrm{~kg} \mathrm{Nha}^{-1}$, and most leaching at Estrup with $205 \mathrm{~kg} \mathrm{Nha}^{-1}$. Drainage mainly occurred when a water table was close to the surface. Drainage was only observed a few times at Silstrup (e.g. July 2001 and 2002, May 2003 and October 2007), when the groundwater table was far below the drainage depth, due to preferential flow. This flow may rapidly take chemicals from the surface to the tile drain system (Kladivko et al., 1999). The combination of sitespecific climatic and hydrological conditions resulted in far greater drainage at Estrup (average $68 \%$ in 2001-2012) than at Faardrup (40\%) and Silstrup (43\%), providing the greatest input to groundwater in the latter two fields.

Besides the transport of nitrate- $\mathrm{N}$ in drainage out of the fields, the prevailing hydrological conditions also strongly influenced the potential for denitrification of nitrate-N released from decaying material such as plant parts and bacteria and other soil fauna and flora. The shallow water table at Estrup for two thirds of the year, together with higher temperatures $\left(58 \%\right.$ at $\left.>5{ }^{\circ} \mathrm{C}\right)$, made the potential for in situ denitrification much greater here than at Faardrup and Silstrup, where a deep water table and vadose conditions impaired the presence of the oxygen-free conditions essential for the denitrification process to occur. Under these conditions, in situ denitrification would be limited to oxygen-free micro-environments.

\subsection{N fertilisers}

Only at Estrup, with its shallow and highly dynamic groundwater table, were the applications of $\mathrm{N}$ fertilisers (inorganic $\mathrm{N}$ fertilisers as well as slurry) reflected in the concentration of nitrate- $\mathrm{N}$, but only as a short-term increase in the nitrate- $\mathrm{N}$ concentration after application. Even though the applications of $\mathrm{N}$ fertilisers at Faardrup and Silstrup were performed at similar plant growth stages, no immediate effects on nitrate$\mathrm{N}$ concentrations were observed. This applied to both inorganic $\mathrm{N}$ fertilisers and injected slurry. This may be because most of the $\mathrm{N}$ applications were performed just around the time of sowing or at the beginning of the growing season when crops efficiently use up available nitrate-N. Gentry et al. (2014) have found that changing from autumn to spring Napplication for maize improves water quality in tiled-drained catchments.

It seems that current regulations concerning the timing of $\mathrm{N}$ application - often in spring - have helped to reduce the immediate impact of nitrate on drainage quality at fields like Faardrup and Silstrup. At Estrup, however, leaching of nitrate could be reduced further if the time for $\mathrm{N}$ application is aligned with the weather conditions so that high intensity rainfall is avoided just after application.

\subsection{Crop types}

The results from all three fields confirmed that the choice of crops and crop rotation had an effect on the leaching of nitrate- $\mathrm{N}$ into drainage, primarily due to their different growth periods. Thus, it is clear that crops with a long growing season (sugar beet, red fescue, winter rape and winter wheat) help to reduce the concentration of nitrate-N compared to crops with a short growing season (maize, spring barley and pea) and thereby leave the land without vegetation for a longer period of time. Red fescue used the applied $\mathrm{N}$ fertilisers most efficiently, and thereby lowered the concentration of nitrate-N to about $1 \mathrm{mg} \mathrm{N} \mathrm{L}^{-1}$. Since crops with a short growing period leave soil bare (without winter cover crops or catch crops) at high air (and soil) temperatures, this favours mineralisation and the release of nitrate- $\mathrm{N}$ that can percolate to the tile drain system or groundwater in winter months (Premrov et al., 2014). Pea in rotation with wheat at Estrup seemed not to increase the concentration of nitrate-N at Estrup (2001/2002), whereas at Silstrup the concentrations increased markedly (2003/2004), which was similar to observations by Beaudoin et al. (2005). 


\subsection{Nitrate- $N$ concentrations}

The nitrate- $\mathrm{N}$ concentrations in drainage exhibited annual and seasonal variability over the 11-year monitoring period. The final nitrate- $\mathrm{N}$ concentrations in drainage were governed by multiple factors, of which climate conditions (precipitation and evaporation) and types of crop were the most significant. Thus, the low precipitation and percolation at Faardrup seemed to be the governing factors behind the field often having the highest nitrate- $\mathrm{N}$ concentration in the drainage even though it had the lowest application of $\mathrm{N}$ fertilisers. Nitrate$\mathrm{N}$ concentrations at Faardrup for most crop types exceeded the EU limit for drinking water. Profitable crop production at reduced input of $\mathrm{N}$ fertilisers may be very difficult in these low rainfall areas, but the right choice of crops combined with growing of catch crops may be a solution for optimal Nmanagement of such fields. The net outcome of catch crops, however, may lead to lower $\mathrm{N}$-fluxes in drainage but higher nitrate concentrations due to the catch crop water uptake and hence lower ground water infiltration.

The monitoring highlighted that crop rotation with crops that have long growing seasons, e.g. red fescue, winter rape and winter wheat, efficiently reduced the pool-leachable nitrate-N. Reduced nitrate-N loss in drainage with cover crops has also been recorded by Drury et al. (2014) when planting a winter wheat cover crop in a cool, humid agricultural soil. The concentrations of nitrate-N at Silstrup and Estrup were below the average concentration of $18 \mathrm{mg} \mathrm{N} \mathrm{L}^{-1}$ measured in drainage from 15 systematic tile-drained Danish agricultural clayey till areas (3-22 ha) in 1971-1981 (Hansen and Pedersen, 1975; Pedersen, 1983).

Unlike at Faardrup, the nitrate-N concentrations at Silstrup and Estrup were often below the EU drinking water limit. Even though the lowest overall nitrate- $\mathrm{N}$ concentrations were recorded at Estrup (highest precipitation), the lowest nitrate$\mathrm{N}$ concentrations were measured at Silstrup under a crop of red fescue that efficiently took up all nitrate-N available.

\subsection{Nitrate-N fluxes}

The results from 2001-2012 showed that the nitrate-N losses were the product of nitrate- $\mathrm{N}$ concentrations in the flowing water, and that the amount of water (drainage) was essential for the total impact on the aquatic environment. Leaching of nitrate-N from Faardrup and Silstrup with a deeply located groundwater table during the summer was concurrent with days of high drainage. At Estrup, where the groundwater table is closer to the surface, transport of nitrate- $\mathrm{N}$ to the aquatic environment was almost continuous. The annual nitrate- $\mathrm{N}$ losses to drainage ranged from 3 to $32 \mathrm{~kg} \mathrm{Nha}^{-1} \mathrm{yr}^{-1}$, with the lowest after winter rape at Faardrup and the highest after winter wheat and rape at Silstrup and Estrup, respectively. However, despite major differences in climate, hydrological pattern and amounts of $\mathrm{N}$ fertilisers applied, the average nitrate- $\mathrm{N}$ losses for 2001-
2011 were between 13 and $19 \mathrm{~kg} \mathrm{Nha}^{-1}$, equivalent to 10 $13 \%$ of the amount applied, with the highest losses at Estrup. This was below the $25 \%$ found in a long-term study by Lucey and Goolsby (1993). The losses in $\mathrm{kg} \mathrm{Nha}^{-1}$ were within the range of 10 and $29 \mathrm{~kg} \mathrm{Nha}^{-1}$ reported for 15 Danish clayey till agricultural areas monitored between 1971 and 1980 (Pedersen, 1983). The average nitrate-N loss for the 15 areas was $22 \mathrm{~N} \mathrm{ha}^{-1} \mathrm{yr}^{-1}$ and therefore higher than the $15 \mathrm{~kg} \mathrm{Nha}^{-1} \mathrm{yr}^{-1}$ on average for the three fields in the present study. The annual nitrate- $\mathrm{N}$ leaching at the three fields fell within the typical range for most European and North American research studies, even though nitrate$\mathrm{N}$ leaching in some studies has reached up to $100 \mathrm{~kg} \mathrm{~N} \mathrm{ha}^{-1}$ (Randall et al., 2008) and up to $105 \mathrm{~kg} \mathrm{Nha}^{-1}$ for poorly drained loess soils (loam soils) in Indiana, USA (Kladivko et al., 1999).

Due to longer periods of high water saturation of the layers close to the surface, including at times of high air (and soil) temperatures and renewable inputs of surface-derived bioavailable organic carbon in the top two metres (Pabich et al., 2001) e.g. from injected slurry, crop material and roots, it was expected that the in situ denitrification process would be more efficient for nitrate- $\mathrm{N}$ attenuation at Estrup than at Faardrup or Silstrup, where most of the year the groundwater table is down to around a depth of $4 \mathrm{~m}$.

\section{Summary and conclusions}

To the authors' knowledge this study presents the first long-term monitoring (11 years) of nitrate- $\mathrm{N}$ concentrations and fluxes in drainage from well-defined tile-drained fields in Denmark. Data collected simultaneously on nitrate-N, drainage, climate (precipitation and air temperature), ground water table, crops (types and growth stage) and $\mathrm{N}$ fertilisers (type and time of application) were collected in 20012012 at three fields across Denmark. The annual average air temperature and evaporation were around the same in all fields, but the average annual precipitation varied between $685 \mathrm{~mm} \mathrm{yr}^{-1}$ (Faardrup) at the lowest to $1089 \mathrm{~mm} \mathrm{yr}^{-1}$ at the highest (Estrup). Major differences in drainage nitrate-N concentrations were identified. Most often the highest concentrations were measured in drainage from the low precipitation field, where concentrations were often above the European limit for drinking water, irrespective of whether the field was with or without crop cover. At the two other fields the nitrate-concentrations in drainage often remained below the EU limit. However, different types of crops strongly influenced $\mathrm{N}$-concentrations, with the lowest nitrate- $\mathrm{N}$ concentrations during and after red fescue and the highest concentrations after a pea crop or crops with a short growing season followed by bare soil. Nitrate-N fluxes out of the fields were primarily controlled by the site-specific hydrological setting and only to a minor extent by the nitrate- $\mathrm{N}$ content in the drainage. The nitrate- $\mathrm{N}$ flux signature of the two fields with 
deeply located groundwater tables at times and only short and medium-length drainage periods showed major nitrate-N leaching events that were concurrent with intense drainage, whereas more even nitrate- $\mathrm{N}$ fluxes were obtained from the field with longer drainage periods. The total impact on the aquatic environment in 2001-2012 due to drainage losses varied between 142 and $205 \mathrm{~kg} \mathrm{Nha}^{-1} \mathrm{yr}^{-1}$, equivalent to $10-13 \%$ of the amount of $\mathrm{N}$ fertilisers applied. In fields with a shallow vadose zone as well as lengthy periods of water saturation, a renewable source of organic matter from crop residues may make the denitrification processes much more efficient, and thereby contribute to lower nitrate- $\mathrm{N}$ concentrations and nitrate- $\mathrm{N}$ fluxes in drainage. The time at which drainage out of the field occurs may also influence the potential efficiency of water management actions off-field, e.g. in natural or small constructed wetlands where the effectiveness due to microbial processes and plant growth is highly temperature dependent. Here, as at Estrup, long-term leaching of nitrate-N, including at higher temperatures, presented the best possibilities for off-field water management actions to reduce the impact of nitrate, whereas the short-term leaching of nitrate at Faardrup at low temperatures presented a limited potential of on-field or off-field water management actions due to the very short period of water saturation at low temperatures. The documented differences in nitrate- $\mathrm{N}$ fluxes and concentrations at a local scale reveal some of the future challenges that need to be addressed when regulating for $\mathrm{N}$ fertilisers at field scale, such as in the regulation already proposed. Future N-regulation cannot be based on a single factor, but has to take a combination of field-specific factors into consideration, such as the inherent physical appearance and agricultural management of the fields. The longterm monitoring has revealed that the outcome of on-field or off-field water management actions could differ between fields with different hydrogeological settings and climatic conditions. This initial well-documented field-scale knowledge from three clayey till fields that are representative of large areas in Denmark is a first step towards establishing a differentiated $\mathrm{N}$-regulation for such areas. A future challenge will be to obtain the necessary knowledge to cover all field types represented within a catchment (van der Velde et al., 2010).

Acknowledgements. This study was funded by the Danish Pesticide Leaching Assessment Programme. The authors would like to thank the many people who have participated in the programme over the past 11 years, especially Finn Plauborg and Finn Christensen for providing climate data, Ulla Husballe Rasmussen and Mette Ejsing-Duun for meticulous analytical work, and Jens Barsballe, Poul Boesen, Hennrik Bruun, Lasse Gudmundsson, Kristine Riis Hansen, Søren Have Jepsen, Jens Molbo, Niels Peter Pedersen and Henning C. Thomsen who collected the various types of data.

Edited by: F. van Geer

\section{References}

Bakhsh, A., Hatfield, J. L., Kanwar, R. S., Ma, L., and Ahuja, L. R.: Simulating nitrate drainage losses from a Walnut Creek watershed field, J. Environ. Qual., 33, 114-123, 2004.

Barlebo, H. C., Rosenbom, A. E., and Kjær, J.: Evaluation of Pesticide Scenarios for the Registration Procedure, Danish Ministry of the Environment, Danish Environmental Protection Agency, Copenhagen, Denmark, 152 pp., 2007.

Beaudoin, N., Saad, J. K., Van Laethem, C., Machet, J. M., Maucorps, J., and Mary, B.: Nitrate leaching in intensive agriculture in Northern France: Effect of farming practices, soils and crop rotations, Agr. Ecosyst. Environ., 111, 292-310, 2005.

Bennetzen, F.: Water-balance and nitrogen-balance by optimal plant-production, 1. Introduction about plant-nutrients and water-pollution with description of the experimental areas, Tidsskrift for planteavl, 82, 81-99, 1978.

Billy, C., Birgand, F., Sebilo, M., Billen, G., Tournebize, J., and Kao, C.: Nitrate dynamics in artificially drained nested watersheds, Phys. Chem. Earth, 36, 506-514, 2011.

Billy, C., Birgand, F., Ansart, P., Peschard, J., Sebilo, M., and Tournebize, J.: Factors controlling nitrate concentrations in surface waters of an artificially drained agricultural watershed, Landscape Ecol., 28, 665-684, 2013.

Breuning-Madsen, H.: Drænrørets indførelse og betydning i et landbrugs-og miljømæssigt perspektiv. In: Det fremmede som historisk drivkraft i Danmark efter 1742, Special-Trykkeriet Viborg AS, Viborg, Denmark, 2010.

Christensen, S., Simkins, S., and Tiedje, J. M.: Temporal patterns of soil denitrification - their stability and causes, Soil Sci. Soc. Am. J., 54, 1614-1618, 1990.

Commission on Nature and Agriculture: Richer nature, new environmental regulation and new growth opportunities for agriculture, http://www.naturoglandbrug.dk (last access: $4 \mathrm{Au}-$ gust 2015), 2013.

Cordeiro, M. R. C., Ranjan, R. S., Ferguson, I. J., and Cicek, N.: Nitrate, phosphorus, and salt export through subsurface drainage from corn fields in the Canadian prairies, T. ASABE, 57, 43-50, 2014.

Danish-EPA: Danish Nitrate Action Programme 2008-2015 - Regarding the Nitrates Directive, 91/676/EEC, Danish Environmental Protection Agency, Copenhagen, Denmark, 2012.

Delin, S. and Stenberg, M.: Effect of nitrogen fertilization on nitrate leaching in relation to grain yield response on loamy sand in Sweden, Eur. J. Agron., 52, 291-296, 2014.

Dinnes, D. L., Karlen, D. L., Jaynes, D. B., Kaspar, T. C., Hatfield, J. L., Colvin, T. S., and Cambardella, C. A.: Nitrogen management strategies to reduce nitrate leaching in tile-drained midwestern soils, Agron. J., 94, 153-171, 2002.

Drury, C. F., Tan, C. S., Welacky, T. W., Reynolds, W. D., Zhang, T. Q., Oloya, T. O., McLaughlin, N. B., and Gaynor, J. D.: Reducing Nitrate Loss in Tile Drainage Water with Cover Crops and Water-Table Management Systems, J. Environ. Qual., 43, 587598, 2014.

EC: Directive 2000/60/EC of the European Parliament and of the Council of 23 October 2000 establishing a framework for Community action in the field of ground water policy, European Commission, Brussels 2000.

EC: Directive 2006/118/EC of the European Parliament and the Council of 12 December 2006 on the protection of groundwa- 
ter against pollution and deterioration, European Commission, Brussels, 2006

EEC: Council Directive 91/676/EEC of 12 December 1991 concerning the protection of waters against pollution caused by nitrates from agricultural sources, Brussel, Belgium, 1991.

Eidem, J. M., Simpkins, W. W., and Burkart, M. R.: Geology, groundwater flow, and water quality in the Walnut Creek watershed, J. Environ. Qual., 28, 60-69, 1999.

Ernstsen, V., Binnerup, S. J., and Sorensen, J.: Reduction of nitrate in clayey subsoils controlled by geochemical and microbial barriers, Geomicrobiol. J., 15, 195-207, 1998.

Gastal, F. and Lemaire, G.: N uptake and distribution in crops: an agronomical and ecophysiological perspective, J. Exp. Bot., 53, 789-799, 2002.

Gentry, L. E., David, M. B., and McIsaac, G. F.: Variation in Riverine Nitrate Flux and Fall Nitrogen Fertilizer Application in EastCentral Illinois, J. Environ. Qual., 43, 1467-1474, 2014.

Gilliam, J. W., Skaggs, R. W., and Weed, S. B.: Drainage control to diminish nitrate loss from agricultural fields, J. Environ. Qual., 8, 137-142, 1979.

Gilliam, J. W., Baker, J. L., and Reddy, K. R.: Water quality effects of drainage in humid regions. In: Agricultural drainage, American Society of Agronomy, Crop Science Society of America, Soil Science Society of America, Madison, 1999.

Hansen, L. and Pedersen, E. F.: Losses of nutrients by leaching in agricultural plant production (in Danish), Tidsskrift for planteavl, 79, 670-688, 1975.

Kladivko, E. J., Grochulska, J., Turco, R. F., Van Scoyoc, G. E., and Eigel, J. D.: Pesticide and nitrate transport into subsurface tile drains of different spacings, J. Environ. Qual., 28, 997-1004, 1999.

Lapen, D. R., Topp, E., Edwards, M., Sabourin, L., Curnoe, W., Gottschall, N., Bolton, R., Rahman, S., Ball-Coelho, B., Payne, M., Kleywegt, S., and McLaughlin, N.: Effect of liquid municipal biosolid application method on tile and ground water quality, J. Environ. Qual., 37, 925-936, 2008.

Lindhardt, B., Abildstrup, C., Vosgerau, H., Olsen, P., Torp, S., Iversen, B. S., Jørgensen, J. O., Plauborg, F., Rasmussen, P., and Gravesen, P.: The Danish pesticide leaching assessment programme, Site characterization and monitoring design, GEUS, Copenhagen, Denmark, 2001.

Lucey, K. J. and Goolsby, D. A.: Effects of climatic variations over 11 years on notrate-nitrogen cencentrations in the Raccoon river, Iowa, J. Environ. Qual., 22, 38-46, 1993.

Meier, U.: Growth stages of mono- and dicotyledonous plants BBCH monograph, available from Julius Kühn-Institute: http: //www.jki.bund.de (last access: 5 August 2015), 2001.

Mulla, D. J. and Strock, J. S.: Nitrogen transport processes in soil, in: Nitrogen in agricultural systems, American Society of Agronomy, crop Sciences of America, Soil Society of America, Madison, USA, 2008.

Nangia, V., Gowda, P. H., Mulla, D. J., and Sands, G. R.: Modeling Impacts of Tile Drain Spacing and Depth on Nitrate-Nitrogen Losses, Vadose Zone J., 9, 61-72, 2010.

Olesen, S. E.: Kortlægning af potentielt dræningsbehov på landbrugsarealer opdelt efter landskabselement, geologi, jordklasse, geologisk region samt høj/lavbund, Det jordbrugsvidenskabelig faktultet, DJF, Markbrug no. 21, Aarhus University, Aarhus, Denmark, 31 pp., 2009.
Pabich, W. J., Valiela, I., and Hemond, H. F.: Relationship between DOC concentration and vadose zone thickness and depth below water table in groundwater of Cape Cod, USA, Biogeochemistry, 55, 247-268, 2001.

Pedersen, E. F.: A study of drainage water 1971-81, Losses of nutrients by leaching in agricultural plant production (in Danish), Tidsskrift for planteavl, Beretning no. S 1667, Statens Planteavlsforsøg, Copenhagen, Denmark, 53 pp., 1983.

Premrov, A., Coxon, C. E., Hackett, R., Kirwan, L., and Richards, K. G.: Effects of over-winter green cover on soil solution nitrate concentrations beneath tillage land, Sci. Total Environ., 470, 967974, 2014.

Randall, G. W., Delgado, J. A., and Schepers, J. S.: Nitrogen Management to Protect Water Resources, in: Nitrogen in Agricultural Systems, Agronomy Monograph 49, edited by: Raun, W. R., Schepers, J. S., Follett, R. F., Fox, R. H., and Randall, G. W., Americal Society of Agronomy, crop Sciences of America, Soil Society of America, Madison, USA, 911-946, 2008.

Robinson, M. and Rycroft, D. W.: The impact of drainage on streamflow, in: Agricultural drainage American Society of Agronomy, crop Sciences of America, Soil Society of America, Madison, USA, 1999.

Rosenbom, A. E., Olsen, P., Plauborg, F., Grant, R., Juhler, R. K., Brusch, W., and Kjaer, J.: Pesticide leaching through sandy and loamy fields - Long-term lessons learnt from the Danish Pesticide Leaching Assessment Programme, Environ. Poll., 201, 7590, 2015.

Rozemeijer, J. C., van der Velde, Y., van Geer, F. C., Bierkens, M. F. P., and Broers, H. P.: Direct measurements of the tile drain and groundwater flow route contributions to surface water contamination: From field-scale concentration patterns in groundwater to catchment-scale surface water quality, Environ. Poll., 158, 35713579, 2010.

Schjonning, P., Lamande, M., Berisso, F. E., Simojoki, A., Alakukku, L., and Andreasen, R. R.: Gas Diffusion, Non-Darcy Air Permeability, and Computed Tomography Images of a Clay Subsoil Affected by Compaction, Soil Sci. Soc. Am. J., 77, 1977-1990, 2013.

Simmelsgaard, S. E.: The effect of crop, N-level, soil type and drainage on nitrate leaching from Danish soil, Soil Use Manage., 14, 30-36, 1998.

Simmelsgaard, S. E. and Djurhuus, J.: An empirical model for estimating nitrate leaching as affected by crop type and the long-term N fertilizer rate, Soil Use Manage., 14, 37-43, 1998.

Tiemeyer, B., Kahle, P., and Lennartz, B.: Designing Monitoring Programs for Artificially Drained Catchments, Vadose Zone J., 9, 14-24, 2010.

Van Der Ploeg, R. R., Horton, R., and Kirkham, D.: Steady Flow to Drains and Wells, in: Agricultural Drainage, edited by: Skaggs, R. W. and van Schilfgaarde, J., Agronomy Monograph, American Society of Agronomy, Crop Science Society of America, Soil Science Society of America, Madison, WI, USA, 1999.

van der Velde, Y., Rozemeijer, J. C., de Rooij, G. H., van Geer, F. C., and Broers, H. P.: Field-Scale Measurements for Separation of Catchment Discharge into Flow Route Contributions, Vadose Zone J., 9, 25-35, 2010. 